\title{
LONGWORTH'S MISSION TO CIRCASSIA IN 1855
}

\author{
Doç. Dr. Musa ŞAŞMAZ*
}

The political history of the Circassian tribes was for a long time intimately connected with that of the Crimea prior to the annexation of the latter to the Russian Empire. The sovereignty of the Sublime Porte was acknowledged by both though never established in Circassia, as in the Crimea, by conquest. It partook rather of the character of religious than temporal supremacy; the Sultan as $\mathrm{Ca}$ liph bearing the supreme head of Islamism.

In the treaty of Kaynarca ${ }^{1}, 21$ July 1774, by which the Crimea was constituted independent, it is declared in article III "Toutes les nations Tartares de la Crimée, du Budziach, du Kuban, d'Yedistan, de Geambouilak, de Sedikul, sans aucune exception quelconque, seront respectivement, par les deux Empires, reconnues libres et entièrement indépendantes de toute Puissance étrangère et comme étant sous la puissance immédiate de leur propre Khan de la race de Cengiz Khan, elu et établi de l'accord et avec le consentement unanime des peuples Tartares, lequel les gouvernera suivant leurs lois et leurs anciens usages, sans jamais rendre compte en aucun temps a aucune Puissance étrangère quelconque, "\&c.

* Academic Staff of Niğde University.

1. Gabriel Noradoungian, Recueil d'actes internationaux de l'Empire Ottoman (Paris, 1897), Vol. I, p. 310; C. de Martens and F. de Cussy, Recueil manuel et pratique de traités, conventions et autres actes diplomatiques, (Leipzig, 1846-1857), 7 Vols.. Vol. I. p. 111; G- de Martens, Recueil de traités d'alliance, de paix, etc., de 1761 a 1808. (Gottingue, 1817-1835), 8 Vols, Vol. II, p. 286; Mecmua-i Muahedat, (Istanbul, 1294-1298), 5 Vols., Vol. III, p. 254; Treaties between Turkey and Foreign Powers. (London, 1855), p. 463. 
This treaty, notwithstanding the connection that had subsisted between Circassia and the Crimea, makes no reference whatever to the Circassian tribes. There may seem to be some ambiguiy in the phrase "nations Tartares du Kuban", but it will be found on examination to apply only to the Tartars residing either on the right bank, or in the delta between the two mouths of the Kuban, and not to the Circassians on the left bank. This was proved by the boundary convention concluded about thet time between the Russian Governor Tolstoy and Hasan Pasha, and the act of 20 December $1783^{2}$ relative to the incorporation to the Russian Empire of the Crimea and the Isle of Taman, and which fixes for limit of the two Empire the River Kuban.

This act, with the other foregoing treaties, is cited in the 2nd article of the treaty of $\mathrm{Yash}^{3}, 24$ December 1792, and all doubt with respect to the Sultan's sovereign rights is removed by the 6 th article of the same treaty, in which it is declared: "Le deuxième Article du présent Traité ayant confirmé entre autres Traités précédents $l^{\prime}$ Acte du 20 Décembre, 1783, relatif a l'incorporation a l'Empire Russe de la Crimée et de l'lle de Taman, et qui fixe pour limite des deux Empires le fleuve du Kuban, la Sublime Porte promet et s'engage solennellement à employer son autorité et tous ses moyens pour maintenir dans l'ordre les peuplades qui habitent la rive gauche du Kuban, et les empêcher de faire des incursions dans l'Empire Russe, ou de porter préjudice soit secrétement soit ouvertement sous quelque prétexte que ce soit aux habitants Russes de la rive droite. Pour cet effet la Sublime Porte enverra à qui il

2. Gabriel Noradoungian, Recueil d'actes internationaux de l'Empire Ottoman. Vol. I, p. 377; C. de Martens and F. de Cussy, Recueil Manuel et pratique de traités, conventions et autres actes diplomatiques, Vol. I, p. 315; G- de Martens, Recueil de traités d'alliance, de paix, etc., de 1761 a 1808, Vol. III, p. 7()7; Mecmua-i Muahedat, Vol. III, p. 319 and Treaties between Turkey and Foreign Powers. p. 508.

3. Gabriel Noradoungian, Recueil d'actes internationaux de l'Empire Ottoman, Vol. II. p. 16; C. de Martens and F. de Cussy, Recueil Manuel et pratique de traités, conventions et autres actes diplomatiques, Vol. II, p.65; G- de Martens. Recueil de traités d'alliance, de paix, etc., de 1761 a 1808, Vol. V, p. 291; Mecmua-i Muahedat. Vol. IV. p. 4; Treaties between Turkey and Foreign Powers, p. 508 and State Papers. Vol. XIII. p. 9() 2$. 
appartient les ordres les plus exprès pour défendre, sous les peines les plus sévères, d'enlever des sujets Russes et de les conduire en esclavage; et elle fera, après l'échange et la ratification du présent Traité, publier sur les lieux ces défenses. Si aprés ces dispositions il arrivait que quelque individu de ces peuplades fit des incursions sur le territoire Russe, dérobat du bétail ou toute autre propriété, ou reduisit en ensclavage des sujets Russes, sur la plainte portée a ce sujet il sera faite prompte justice,. "\&c

Thus, it can be clearly demonstrated that by the mutual consent of the Porte and the Cabinet of St. Petersburg, the Circassian tribes inhabiting the left bank of the Kuban were held to be under the sovereignty of the Sultan. A different understanding was adopted with respect to the two Cabardas. By the 21st article of the treaty of Kaynarca it was settled that "les deux Cabardes c'est-à-dire, la grande et la petite, étant par leur voisinage avec les Tartares en une plus grande connexion avec le Khan de Crimée, il est réservé au dit Khan de consentir avec son consentir avec son conseil et les anciens de la nation Tartare que ces pays appatiennent à la Cour Impériale de Russie."

But the whole of the country inhabited by the Circassian tribes from the left bank of the Kuban to the sea-cost was acknowledged by Russia to belong to Turkey. Anapa, which was taken by the Russians in 1791, was restored to the Porte in 1792. As to the Circassians themselves, they were willing enough to be considered subjects of the Porte and that she should be held responsible for all the disorders they committed on the frontier. But though many Circassian chiefs were appointed and paid by the Porte to keep peace on the border, all these arrangements proved abortive, the marauders were unchecked and the Porte continually embroiled with the Russian government. The fact is the Porte never exercised any real authority on those quarters and these stipulations were, as far as the Circassians were concerned, based on a diplomatic fiction, viz., their subjection to Turkey, whereas they had aways been independent de facto. Anapa was the only point on the coast where the Ottomans had a permanent footing, which the Circassians were 
glad to concede to them as the chief mart of the slave trade- the true and material bond of connection which had at all times united Circassia to the Ottoman Empire. It should be at the same time remarked that the fact of supplying slaves for the Turkish market must in the eyes of the Ottomans have disentitled Circassia to be considered Turkish territory since no born subject of the Sultan who was a Muslim could be sold as a slave.

By the treaty of Edirne ${ }^{4}, 14$ September 1829 , this nominal sovereignty was transferred from the Sultan to the Emperor of Russia. But, though deriving his title from this treaty, its very terms betray an awareness that there is nothing serious or substantial in it. Nothing is said about a cession of territory, not a word about Circassia, no allusion made to the tribes and extensive provinces situated between the Black Sea and the Kuban, but in tracing the limits of the two Empires as then adjusted, the 14th article contains a simple declaration to the effect that certain provinces of Caucasia there mentioned, "ainsi que le littoral de la Mer Noire, depuis l'embouchure du Kuban jusqu'au Fort St. Nicholas inclusivement, serait sous la domination de l'Empereur de la Russie." The reason for this suppression and the appropriation of a whole country, without even naming it, may to some extent have been that Russia wished to draw as little attention as possible to the territorial aggrand-

4. Gabricl Noradoungian, Recueil d'actes internationaux de l'Empire Ottoman. Vol. II, p. 166; L. Neumann and A. de Plasson, Recueil des traites etc... (Vienne), Vol. VI. p. 489; Mecmua-i Muahedat, Vol. IV, p. 4 and G.-Fr de Martens, Nouveau recueil de traités d'alliance de paix, etc. de 1808 a 1839, 16 Vols. (Góttingue, 1817-1842). Vol. VIII, p. 143. For the situation in and the description of Circassia from 1829 to the beginning of the Crimean War, see Baron von Haxthausen, Transcaucasia, Sketches of the Nations and Races between the Balck Sea and the Caspian. (London, 1854), pp. 1-13; Edmund Spencer, Travels in Circassia, Kırım Tartary, including a Steam Voyage down the Danube from Vienna to Constantinople, and round the Black Sea, (London, 1839), II Vols., especially Vol. I, p. 238f.; Richard Wilbraham, Travels in the Transcaucasian Provinces of Russia and Along the Southern Shore of the Lakes of Van and Urumiah in the Autumn and Winter of 1837, (London, 1839), pp. 224-226: Xivier Hommaire de Bell, Travels in the Steppes of the Caspian Sea, the Crimea, the Caucasus. (London. 1847), p. 297f.; For the military operations of Russia between 1830 and 1852, see W. E. D. Allen and P. Muratoff, Caucasian Battle-fields, a History of the Wars on the Turco-Caucasian Border, (Cambridge, 1953), pp. 46-53. 
izement she had in view and against which she was pledged at the commencement of the war. But in reality, if not politically, the Russian government both before and after the treaty of Edirne, looked upon the Circassian tribes as independent. They were so marked in the official maps drawn in the early 19th century which enumerated the population to discriminate between dependent and independent tribes.

During the discussion of the question raised by the capture of the merchant ship Vixen ${ }^{5}$, which was taken by the Russians while attempting to break the blockade of the coast of Circassia in 1837 , the British government avoided any recognition of the de jure or de facto sovereignty of Russia over Circassia. The seizure of the vessel was admitted to be valid on the ground that it had entered the port of Sucukkale which belonged to the Ottoman Empire at the period of the conclusion of the treaty of Edirne and was then under Russian military occupation. In the opinion of the British government, at that time Russia had no legal claim to any part of the Circassian territory which she did not hold, nor did the Ottoman empire have a right to cede what she never possessed ${ }^{6}$.

Amids the political complications which surrounded the question of Circassia, it was found very difficult, if not impossible during and after the Crimean War, to arrive at any satisfactory solution. In that period, three distinct modes of settlement presented themselves, viz., the sovereignty of Russia, the sovereignty of the Ottoman Empire, and the independence of the Circassian tribes. None of them was considered acceptable by the British government, because all consequently withdrew their forces from the coasts. In this period, the British and French officers entertained to establish a kind of permanent presence in the Caucasia, because

5. For the Vixen affair, see Norman Luxenburg, Russian Expansion into the Caucasus and the English Relationship Thereto, Unpublished Ph.D Dissertation, (University of Michigan, 1956), pp. 98-150.

6. See inclosure I in J. A. Longworth to the Earl of Clarendon, no 37, 17 January 1856, FO 881/545. 
they were aware that, as soon as Russia was on her knees she would try to take positions which she had lost in the war. So the British and French governments with a view to strengthening their positions, were committed to securing the active cooperation of the Circassian tribes in the war against Russia, and the British government, therefore, proposed to send J. A. Longwarth, who had resided there for some time, and of whose ability and discretion the British govrenment was well assured. The British government contemplated persuading the French government to send a French agent to accompany Longworth, so as to make this mission of enquiry look more important in the eyes of the Circassians. If the French government thought otherwise, Longworth's departure was to be postponed until Longworth's French colleague was ready to accompany him. To this purpose, Clarendon, the British Foreign Minister, wrote a letter on 9 April 1855 to Lord Cowley, the British Ambassador in Paris, to find out whether the French government was to assign a French agent to accompany Longworth for the mission to be proceeded to Circassia. In accordance with this instruction, Lord Cowley communicated with $\mathrm{M}$. Thouvenel, the French Foreign Minister, on the subject of Longworth's mission and the result was that the French government had already sent an agent namely $\mathrm{M}$. Champoiseau, to Batum for the purpose of proceeding thence into Circassia. After this communication, $M$. Thouvenel ordered M. Champoiseau to wait at Batum to receive further instructions from his government. The French government desired to furnish his agent instructions similar to those issued for Longworth. At M. Thouvenel's request, Lord Cowley left them with him, in order to frame similar ones for M. Champoiseau?. The British Foreign Minister, the Earl of Clarendon, also instructed his Ambassador at Istanbul, Lord Stratford de Redcliffe, to communicate with M. Benedetti, the French Ambassador at Istanbul on the subject. Clarendon found it necessary to communicate the information to be given to Longworth with the Russian government in the event of his proceeding to Circassia alone ${ }^{8}$.

7. Lord Cowley to the Earl of Clarendon, no 440, 13 April 1855, FO 881/1443.

8. The Earl of Clarendon to Lord Cowley, no 364, 9 April 1855, 881/1443. 
The Foreign Minister, Clarendon, sent to Stratford de Redcliffe and Longworth on 13 April 1855 the details and the instructions about Longworth's proceeding to Circassia. In his letter to Redcliffe, Clarendon asked him to supply Longworth with the necessary funds from his account of extraorinary disbursement, to facilitate his proceeding to the coast and to obtain for him from the British naval and military authorities, or if necessary from the Ottoman arsenals any supplies to be entrusted to him for distribution. For these arrangements Clarendon stated that he had applied to the British War Department and to the Admiralty to give the necessary authority for the issue of such supplies available in the British stores and to convey Longworth and the supplies to the coast of Circassia in a ship of war. Redcliffe was also requested to obtain from the Ottoman government a decree making Longworth the bearer of an autharitative disclaimer from the Porte of all intention hereafter to claim sovereignty over Cirassia. This decree was found essential to wipe out the suspicions of the Circassian tribes as to the views of the Porte".

As for Longworth's instruction to go to Circassia, the British government was desirous to obtain accurate information as to the state of affairs in that country in 1855 , and as to the extent to which the allies could count on the cooperation of the various tribes inhabiting that country, if circumstances rendered it advisable to call them into action. To this purpose Longworth was asked to proceed at once to such place on the Circassian coast to afford the readiest opportunity for communicating with the most influential chiefs of the different tribes.

The ostensible object of Longworth's visit was to inquire into the amount of cavalry which the Circassian tribes were likely to place at the disposal of the British government. All arrangements were made for him to obtain, in Istanbul, a supply of gunpowder as well as a supply of riffles and mountain guns. If they were found

9. The Earl of Clarendon to Lord Stratford de Redcliffe, no 291, 13 April 1855, FO $881 / 1443$. 
insufficent in the British army stores in Istanbul, he would ask them from Britain. Soon after his arrival, he was to endeavour to place himself in communication with Shamil, and learn the state of his position with reference to the other tribes, of his intentions and plans with regard to carrying on hostilities against Russia. Another duty of Longworth was to inquire into the state and resources of the Circassian tribes, in general, for active warfare of the country, whether the feuds among the different tribes would prevent their united action even against a common enemy, what prospect they would be of their future consolidation, under what form of government, and what sort of assistance they would desire of accept from the allies, and what guarantees for their protection against Russia they would look hereafter for in return for their more active assistance in the war and so on.

He was however warned to abstain from pledging the British government to anything beyond the existing assistance in carrying on with the war, not to give a political character to his visit to that country and not to raise expectations impossible to realize, but he was encouraged to state in general terms that his government took a great interest in the struggle which the Circassian tribes had so long prosecuted against Russia, and would see this struggle terminated to the advantage of the several tribes with pleasure. He was also allowed to point out that at all events the cooperation of the tribes in the hostilities in progress could not place them in a worse position than that which they had at that time. While assisting the allies in their endeavours to circumscribe the power of Russia, the Russia, the British government pledged that they would take the surest means of securing for themselves the independence which they had so long striven to maintain ${ }^{10}$.

In consequence of Clarendon's letter addressed to Lord Stratford de Redcliffe, on 13 April 1855, the latter appealed to the Porte to obtain a declaration in favour of Circassian independence after

10. For the detailed instruction, see the Earl of Clarendon to Longworth, no 1 Confidential, 13 April 1855, FO 881/1443. 
the expulsion of the Russians from their country. This appeal was met with favour and the Porte issued a decree in the form of a firman. The decree was addressed to the commander of the army of Batum, the commandant of Sukumkale and its neihgbourhood and to Mustafa Pasha. The Sultan declared in the decree that his government and his intimate allies, the governments of Britain and France, in the continuation of the war with Russia, desired to liberate the countries of Circassia from Russian dominion. To this aim, the British government had sent Longworth to Circassia to inquire into the measures, local and military, necessary for producing a collective movement of the Circassian tribes against the common enemy and for ensuring the end in view. The decree added that Longworth was instructed to act in concert with the French agent $M$. Champoseau at Batum. As they were both distinguished and confidential agents, the Circassian tribes were asked to show them every courtesy and pay attention to what these agents stated concerning the common object. The Sultan further pointed out that the sincere aim and intention of the three imperial governments was to hasten the liberation of Circassia from the grasp of Russia, to save the Circassian people from the troubles and difficulties they had for some time been plunged into, to ensure their welfare and prosperity, and to respect and preserve the national rights and privileges enjoyed of old by the Circassian race and the chiefs of the tribes"

Before coming to Istanbul, Longworth had been performing the consulate of Monastrr. Longworth, together with Alfred Sandison, proceeded to Istanbul and arrived there on 13 May 1855 from which time to 5 June he engaged in making the necessary preparations for the mission. He received his deteailed instructions and the decree from the Sublime Porte with pledges and assurances as to Circassian independence. The mountain guns, minie riffles and ammunition were placed at Longworth's disposal to be given as a present to the Circassians. He also received from the British Am-

11. For the decree, see Lord Stratford de Redcliffe to the Earl of Clarendon, no 422, 11 June 1855, FO 881/1443 and N. Luxenburg, Russian Expansion into the Caucasus and the English Relationship Thereto, pp. 196-197. 
bassador funds to the amount of 1000 Sterling. On receipt of the intelligence indicating the projected attack on Anapa, it was deemed advisable that he should proceed thither with as little delay as possible. He was then boarded on the British ship "Caradoc" by which he was taken to Kertch. The articles and materials to be transported to Circassia could not be shipped on this vessel conveniently and so Longworth had to leave them behind so that they were to be loaded on and conveyed to him by another. The British Ambassador at Istanbul therefore applied to Rear Admiral Sir Edmund Lyons for a steam vessel. Accordingly, the latter dispatched the order to the captain of the "Cyclops" at Sivastapol to proceed immediately to Istanbul to the purpose of transporting the persons and effects left behind. It seems that the vessel "Cyclops" could not come to Istanbul and another vessel namely "Niger" was provided on 10 June 1855 to take him from Kertch to Sucukkale or Anapa ${ }^{12}$. The following day Longworth was conveyed to the shore of Anapa by a ship namely "Highflyer". He observed there that the Russians had evacuated their garrison from Anapa on 7 June, and 28 May they had also abondened Sucukkale. The withdrawn forces of the Russians were reported to amount to 8000 . While they were withdrawing their forces, they destroyed the bridges standing at the mouth of the Kuban. The fortresses of Anapa had also been most effectualy dismantled. Al the guns, 102 in number, had been spiked and 77 of them irremediably damaged by the destruction of the trunnions. The powder magazines had been blown up, and several wide bridges opened in the walls by which the Russians had intended to ruin the defences of this fortress. Sefer Pasha ${ }^{13}$, a Circassian acting un-

12. Longworth to the Earl of Clarendon, no 4, 24 June 1855, FO 881/1443. It is observed that sometimes later the vessel "Cyclops" also appeared off Anapa.

13. Seter Pasha was by origin a Circassian from the neighbourhood of Anapal, where he was known by the name of Zanaoglu Sefer Beg. Through family influence and connection als well as personal merit he formerly enjoyed great credit, and soon after the war between Russia and the Ottoman Empire, which terminated in the treaty of Edirne. he was deputed by his countrymen as their representative to Istanbul, with a view to moving the sympathy and procuring the assistance of the Porte and the Western Powers in the unequal struggle which they continued to maintain against Russia. It was in this capacity of Circassian envoy that he attracted the notice of M. Boutinieff, the Russian Minister, who in 1836 demanded his expulsion from Istanbul. Since that time he lived as a pensioner of the 
der to command of the Ottoman General Mustafa Pasha at Sukumkale, arrived at Anapa with a small personal escort on 10 June, after having taken possesion of that place. Having liberated these places from the Russian occupation the Ottoman officers intendedto appropriate the fortresses in Circassia. This was met with cool reception by the British authorities who wished to protest against such an assumption. To them these fortresses had been for many years in the possession of Russia. In a conference held by Admiral Steward and the French Admiral, the representatives of the allies, Sefer Pasha talked of repairing the breaches, remounting the guns, and putting the fortresses in a good state of defence again. The Ottomans had a view to making these places strongly defensible against any eventual Russian attacks, but it appears that this intention was not supported by the British or French, in fear that it might harm their general interests in the Caucasus. Longworth, in his conversation with the Ottoman military commanders, such as Halid Pasha, expressed his dislike or objections to such Ottoman acts and stated that the possession of Anapa could only be claimed on the grounds of temporary occupation for military reasons, and that it was only in this light that placing an Ottoman garrison in Anapa was admissible. However the question of future possession of the place, he pointed out, was of a political nature and this matter could only be settled by the common accord of the al-

\footnotetext{
Porte at Edirne till the breaking out of the hostilities induced her to avail herself of his services as a political emissary in Circassia. For more than fourteen months he remained in a state of inactivity at Sukumkale on the southern coast of Abhasia, a port of the country in which his influence had at no time prevailed and where he had to contend against that of a formidable rival, the popular and energetic Naib of Sheyh Shamil, Mehmed Emin Efendi. who had also been invested with the title of Pasha by the Porte. It was only after the Russians hald evacuated Anapa and Sucukkale that he ventured to appear in the northern provinces of Shapsu and Natakoych. However, during the twentyfive years that he had been absent, a decided change had taken place in the political character of these districts, nearly atl his influential contemperaries of a former period had disappeared from scne, and the new generation had been very much Russanised. For these. see Longworth to the Earl of Clarendon, no 3, 21 June 1855, FO 88/1443. Also about Sefer Pasha and Mehmed Emin's arrival and his doings up to the Crimean War from pro-British and anti-Ottoman points of view, see Shauket Mufti, Heroes and Emperors in Circassian History, (Beirut, 1944), pp. 207-224.
} 
lied and beligerent governments. He said that it was difficult to see what advantage the Porte could derive from the possession of anapa, since it did appear to him that evidently the Russians had not the slightest intention of reoccupying the town and that it was in fact in its actual state untenable by any Power, friendly or hostile. He further stated that the French and British Admirals having visited it decided on leaving it unoccupied and that the position was isolated and unconnected for strategic purposes with any other, nor could its possession have the slightest bearing on the success of operations in the Crimea or elsewhere. Longworth came to a conclusion that whatever disavowal of ambitious views of the Porte or its agents, the circumstances afforded very conclusive evidence of an intention on its part, not only of recovering the fortified places which it had formerly possessed on the coast, but ettending its authority, temporal as well as religious, over the whole of Circassia. Longworth's fear became stronger when he confined himself to the statement made by Sefer Pasha to the effect that he was in possission of a firman investing him with authority as civil and military governor of all the Circassian provinces situated between the Black Sea and the River Kuban ${ }^{14}$. At that time, the Ottomans maintained a force of 1500 men at Sukumkale and of 500 at Tupse. The problem was that they had difficulty in transporting them to Anapa. Mustafa Pasha had applied for the steamers to the British and French naval commanders but his request was not complied with ${ }^{15}$.

On 21 June, Halid Pasha, the general of a division, came to Anapa in a screw steam-frigate with a brig of war in tow and threefour small transports conveying on board a battalion of Ottoman infantry which was then disembarked and quartered within the walls of the fortress. Halid Pasha's explanation for this act was that he had been ordered by Mustafa Pasha, the Ottoman commander inchief at Batum, to occupy the place. The latter was to follow him with an additional force in a few days. On 23 June, Mustafa Pasha brought a company of Tunisian infantry. He stayed there overnight

14. Longworth to the Earl of Clarendon, no 3, 21 June 1855, FO 881/1443.

15. Longworth to the Earl of Clarendon, no 2, 11 June 1855, FO 881/1443. 
and early the next morning proceeded to the Crimea with the intention of conferring with Omer Pasha and the allied admirals as to the combined plan of operations. Longworth had an opportunity to converse with Mustafa Pasha. The former explained to the latter the object of his mission and probably expressed his fear about the military arrangements being taken by the Ottoman army in Circassia. Mustafa Pasha used very cautious and evasive languages to reply to his statements. It appears most likely that Mustafa Pasha was informed by Halid Pasha of the British remonstrances on the Ottoman military movement at Anapa. Mustafa Pasha therefore wished to avoid raising the subject and told Longworth that he would return to Anapa in the course of a week and would be glad to attend to any communication Longworth was to make ${ }^{16}$. Mustafa Pasha returned to Anapa from Kertch on 26 June 1855 and two days later he gave an audience to the Circassians. In this assembly he read two Imperial firmans. By the first of them he was appointed governor-general of Circassia. Moreover, he was authorized to name kaymakams over any district thought proper. The second firman which was referred to the French and British missions in Circassia contained a pledge on the part of the Sultan to respect the old independence and original national privileges of the Circassians. In Circassia Longworth observed that the Circassians were the adherents to the Sunni sect, and consequently acknowledged the complete supremacy of the Sultan. Although he wanted to raise his objections to this, he found it unseasonable, since the Circassians themselves would have been the first to resent it. In fact, Longworth tried to intrigue amongst the Circassians, but, as he admitted, on political matters they always preferred referring to the Ottoman commander in-chief or Sefer Pasha. In other words the loyalty of the local people to the Ottoman Sultan was unquestionable and this was made firmer by possession by the Ottoman troops of Anapa and the other places on the coast.

One of the aims of the British government for sending a mission to Circassia was to levy irregular cavalry for Britain. This de- 
mand was discussed at an assembly held at Anapa amongst the chiefs and notables of the neighbouring districts, the Ottoman and the British officials. Though the overture was warmly seconded by Mustafa Pasha, the commander-in-chief at Batum, it did not meet with much favour of the Circassians. Longworth believed that their backwardness played an important role in their reaching this decision. The Circassians however declared that while they were threatened by the forces which Russia had collected along the whole line of the Kuban, they would have no cavalry to spare for foreign service, but that when relieved from this danger, they would, with the sanction of the Porte, furnish any contingent that might be required from them. In Longworth's opinion this answer was by no means a final decision and did not necessiate the postponement of the levy altogether, because the reason assigned was an unfounded pretext. He further stated that the Circassian rejection was based on fear of Russia ${ }^{17}$.

Longworth went on an excursion of twelve days into the interior of Circasia from 2 to 14 July 1855. Having visited the interior of the country, Longworth returned to Anapa and observed that the British ship "Leopard" also arrived at this town, having on board eighty French artillerymen under the command of two superior officers of artillery and engineers directed under a convention signed by the French, British and Ottoman commanders-in-chief in the Crimea to blow up the seaward defences of Anapa and, if found desirable, to repair the fortifications on the landside. These instructions were considered peremtory and had been issued under the apprehension that the Russians might re-occupy the place. This presumption seemed to both Longworth and Sefer Pasha improbable, that the Russians could return to Anapa under the existing circumstances. Sefer Pasha therefore decidedly set his face against it, declaring that he could not give his consent till he received orders to this effect from his superior in command, Mustafa Pasha at Sukumkale or Batum. Sefer Pasha persisted in his opposition and

17. Longworth to the Earl of Clarendon, no 5, 2 July 1855, FO 881/1443. 
threatened the British and French representatives there with a protest that the measure was directed against the Circassians. He therefore talked of raising twenty thousand Circassians for the defence of Anapa against the detachment which had been sent to destroy the seaward fortifications. This opposition displayed by the Pasha on this and other occasions was considered unacceptable and useless. Longworth felt annoyed and humiliated by the repeated opposition of Sefer Pasha and the other Ottoman authorities. On seeing his French colleague, M. Champoiseau who arrived at Anapa on 14 July 1855 by the "Leopard", he complained about the unacceptibility of the administrative authority at Anapa exercised by the Ottoman officials, because this authority in his opinion had not been constituted or sanctioned in concert with the allied Powers ${ }^{18}$.

Longworth prepared a long and detailed dispach about his twelve day excursion. His principal object was to persuade the people in those areas to enrol in the British army, because he had failed to levy from the Circassians on the coast. He alluded in his dispatch to the difficulties raised by the Ottoman authorities who were averse to his proceeding into the interior. Sefer Pasha apparently endeavoured to dissuade him under various pretexts, by stating that travelling was unsafe. Mustafa Pasha had also strongly recommended him not to leave the coast. He suspected they had tried to put forward several obstacles to his going to visit the interior of the country. This meant to him that they were concealing their double-dealings and intrigues. Despite this accusation directed against the Ottoman authorities, on his request he was given by Mustafa Pasha and Sefer Pasha three mihmandars to accompany him. His excursion was confined to the section of Circassia forming the north-western angle, between the River Kuban and the Black Sea and inhabited by the tribes of Shapsugh and Natkoych. He first proceeded to Bzadugh and the other provinces extending from some leagues below Ekaterinodar to the sources of the Laba and the Kuban. The feudal chiefs of Pshees and Uzdens preserved the author- 
ity in these areas. Longworth had been to this country for the first time around 1838 and had acquainted many chiefs, but almost all of them were unfortunately dead. Their survivors or successors could provide him no good, because they possessed no weight or influence in the country.

He observed that the encrouchments of the commoners on the privileges of the nobles had been the cause of division. The latter were alienated from their countrymen and the former had readily accepted bribes from the Russian government which was deceived however as to the amount of advantage it could obtain through these means. The Russian government found to its cost that it had to purchase not individuals but a whole population. Still in 1855 , by its conciliatory policy and the concession of commercial facilities including a connivence at the slave trade, it made great progress in the pacification of the Kuban provinces. The principal check it sustained was in the reactionary movement headed by the famous Naib or lieutenant of Shamil who had been occasionally visiting the inhabitants of Shapsugh and Natkoych. They were sometimes fined, confiscated and put to death because of the disloyalty to the cause which Shamil was fighting to achieve. Some of these people, for instance those of Uzdens preferred taking refuge and even service with the Russians. The great majority of them however returned to Circassia after the evacuation of anapa in 1855 and together with some of their countrymen, formed a very numerous body who gave their support to Sefer Pasha, mentioned previously. Longworth claimed that it was Sefer Pasha who prevented the recruitment of the Circassians in the service of the British army.

He then proceeded to another part of Bzadugh and the other provinces of Kuban where the nobles he knew were possessed of substantial authority, which would enable them to dispose of their warlike resources for the benefit of the common cause. All these districts bordering on the Laba and the Kuban, namely Bzadugh, Hatukoy, Demigoy, Beslenoy and Karachay along with those of the Great and Little Kabarda, had, from their contiguity to the Russian frontier, as well as to that they were situated on the plains, main- 
tained peaceful relations with Russia, and had become either neutral or subject to her. The nobles, from the power and influence they possessed, offered satisfactory guarantees for the security of the frontier to some degree. Many of them had even enrolled in the service of the border police. Over twenty thousand families, Tartars and Circassians, who were most exposed to the inroads of the hostile tribes inhabiting the mountains of Abhasia, had emigrated across the Kuban, where lands had been alloted to them. Living there among the Cossack population, they appeared to be dangerous to the Russian government, when war broke out in 1853. In 1855 an ukase arrived from St. Petersburg, ordering the emigrants to be removed to the distance of 100 versts into the interior of Russia, or to be allowed to return to Circassia. Many chiefs availed themselves o this permission, well aware that they would in future have to side with their countrymen against Russia.

Longwort approached the stream of Afips- a confluent of the Kuban which seperates Shapsugh from Bzadugh where the commoners had risen against the nobles (Pshees and Uzdens) with a determination to overthrow their authority and privileges. The avowed instigator of this movement was the Naib Mehmed Emin Pasha who at the head of 500 horsemen from Abassah, had proclaimed that feudal distinctions were opposed to the precepts of the Quran, which held all Muslims equal in the eyes of the God.

These levelling doctrines were eagerly embraced by the commoners (Tokavs) of Bzadugh, who, of themselves, were, in point of numerical strenght, much more than a match for the Uzdens. Longworth invited the Naib Mehmed Emin Efendi to a conference. He accepted the invitation, but later failed to go to the rendezvous. Longworth somehow talked to the Naib who stated that his reason for not receiving Longworth with the customary honours was that when he had previously sought to cultivate friendly relations with the agents of the British government, he had fallen into disgrace in Istanbul, that in consequence of his having paid a visit of ceremony to the British Ambassador, he had incurred into serious displeasure with the Porte, and that subsequently, on his return to Circassia, his 
friendly reception of the two British agents, Captain Brook and Captain Hughes, had also given offence to Mustafa Pasha, who had, in consequence, witheld a sword of honour and a declaration which had been sent to him by the Sultan.

In fact, the reason for the Naib declining to meet Longworth was that the Naib did not tend hto discuss matters over which he had absolute authority in Circassia. The Naib did not wish to give a share to Longworth and therefore did not meet with him. As the Naib was mainly supported by the majority of the Circassians, the commoners (Tokavs), Longworth found it desirable that the British government should support and maintain the authority and privileges of the nobles, Uzdens, by which action the British government was likely to be furnished with a contingent of irregular cavalry from the Circassians. Their assistance was considered as valuable in the event of an expedition being directed against the communications of Russia with her Trans-Caucasian provinces. To this purpose, an expedition was to be undertaken either on the line of the Kuban with the cooperation of the Muslim tribes or from the south-eastern coast of the Black Sea through the countries of abhases and Mingrelians. The first choice seemed to present many advantages to the British compared to the second one. The plains of the Kuban, from Anapa to the sources of that river, abounded in every resource which an army could require. They were well watered, and would yield plentiful supply of cattle and provisions. The inhabitants, as far as the Kabarda, were eager to make war against the Russians, and would rally enthusiastically around an expeditionary force in that quarter, but the inhabitants in the neighbourhood of Ekaterinodar were at war amongst themselves. It was deemed vital to keep peace among the tribes and to stop the Naib fomenting the civil dissensions if thi idea of expedition was to be put into action.

Longworth bitterly criticized both civil and military officials adminisitering Circassia in terms of both civil and military. For the civil one it was the Naib kept responsible almost for all the civil administration. He first made his appearence in Circassia at the time 
of active resistance against Russia. He, as disciple and lieutenant of Shamil, began to propagate the doctrines of Shafithere, by which all intercourse with Christians was held to be a contamination and a curse. Such a principle, though applicable only to the Russians, was of course favourable to the prosecution of war to the last extreme. The Naib thus grew more popular and powerful. Longworth accused him of having behaved with cruelty and rapacity, an accusation which was most probably originated from Longworth's prewudice against the Naib, who stood against the British aims, for instance, the levy of cavalry from the Circassians. Before the commencement of the war his extent of power was unknown in detail. However it was pretty clear that during the war he revived the old feeling of loyalty to the Sultan as Caliph and the supreme head of the Muslim faith and afforded the Ottomans access to the coast. Longworth asserted that, prior to the war, he had been accustomed to denounce the Osmanlı and their sovereign as a degenerate race of Muslims and he had even substituted the name of Shamil for that of the Sultan in the weekly prayers for the Caliph's health and prosperity. Longworth claimed that there unquestionably existed a desire to found a new Empire in the Caucasia, based on the principles of Muslim belief and domination and believed that this scheme had not been abondaned by the Naib, but only adjourned to more propitious moments. Meanwhile, he found it convenient to temporize as the only means of retaining any share of power and influence, because he had to present himself as a humble suitor in Istanbul. He was however disappointed in his expectations there and he next addressed the representatives of the Great Powers. It appears that the impression he made of the British Ambassador in Istanbul was not very favourable. Longworth pointed out that at first he had not understood the coolness of the British Ambassador to the Naib's advances clearly, until he was fully acquainted with the artful and dangereous character of the Naib.

If the British government were to prioritise between the Porte and the Naib for the accomplishment of its own views in Circassia, Longworth was sure and had no hesitation in giving his preference 
to the former, because the British government could deal more confidentially with the Porte than what he described as the compound of cunning and ignorance one could see in the Naib. Longworth was throughly convinced that the civil and military functionaries appointed by the Porte to conduct her affairs in this quarter were most unfortunately selected. Every person, such as Mustafa Pasha, Sefer Pasha, Mehmed Bey and partly Behcet Pasha, all of which had been selected and appointed, evidently landed in Circassia with an idea that they could only repossess all the old Ottoman possessions ceded by treaties to Russia on the coast, but also make themselves masters of the whole country as far as the Kuban. All this, they imagined, was to be done without the acquiescence of the allied Powers. Hence their jealousy and anxiety to prevent British and French agents from penetrating into the country. In other words, while the presence of such persons would have been to advantageous to the common interests of the allied Powers, they were thought to harm the unity of the allies and it was therefore thought proper to advice the Porte to withdraw them and appoint the accredited persons in their place. Longworth remarked that the agent of the Porte in Circassia should be fully informed as to the nature of this influence, so as not to confound it with civil and military authority and that the authority exercised by the Porte should be equivalent to the material advantages it offered. This proportion should also be applied to the British and French governments. THe explanation given above necessiated a complete revision of the policy adopted by the Porte with respect to Circassia. The best measure for Britain and France was to suspend all their negatiations with the Circassians ${ }^{19}$.

On 20 July 1855 Longworth and his French colleague, M. Champoiseau, visited Prince Michael known to the Turks by the name of Hamid Bey. He was the chief of the Christian tribe of Abhases, and acknowledged till lately the sovereignty of Russia, holding at the same time the rank of lieutenant-general in the Russian 
service. The withdrawal of the Russian forces from Sukumkale at the commencement of the war forced him and his people to go under to control of an occupying force which might be landed there by the allies. Upon the occupation of this place by a detachment of Ottoman troops, he fled and took up his abode at the Russian headquarter till the end of May 1855, when he returned to the neighbourhood of Sukumkale. He made his peace with Mustafa Pasha and agreed to place at his disposal a body of 600 or 700 irregular troops composed chiefly of Muslims. When the British and French agents visited him in his residence, he complained about the Ottomans propagating their faith and establishing their rule in Circassia. He therefore asked for the protection of the British and French governments. In consideration of the support he was to receive, he declared his readiness to subscribe to the same conditions as those on which he had previously held his Principality under the Emperor of Russia. Accordingly, he was to levy an irregular force of 10.000 men who were to be placed at their disposal whenever they wished to use it. He also promised to obtain the cooperation of the government of Mingrelia, the reigning prince of which was related to him by marriage. The conversation made with Prince Michael reminded Longworth that the occupation by Ottoman forces of places in Caucasia populated by Christians had not given good results. The Muslims in Caucasia were inclined towards the Ottoman control, whereas the Christians looked favourably to Russia. If any military operations directed against the places populated by the Christians in Caucasia, for instance Georgia, were on the agenda, they should be made not by the Ottoman army but by the British and French forces, so as not to push them to the mercy of the Russians ${ }^{20}$.

All endeavours of Longworth from early June to the end of July 1855 were fruitless and the mission aiming at the furtherance of British objects in the Caucasia failed, as far as British interests and aims mentioned in Longworth's instruction of 13 April 1855 were concerned. However Longworth's visit to Circassia brought

20). Longworth to the Earl of Clarendon, no 8, 25 July 1855, FO 881/1443. 
into light the fact that the allies were not cordially acting together in the Caucasia and that the British government, having something at the back of its mind, planned to settle the affairs administratively and militarily in Circassia, despite the jealousy of the Ottoman Empire.

It is inferred from Longworth's dispatches that he coud not accomplish his mission. He felt disheartened and left Circassia for Trabzon without achieving the goals for which he had been sent to the Caucasia. Prior to his leave, he underlined the points which were necessary for the furtherance of British objects. They were three altogether. The first of them was the question of the position or the state of the Naib Mehmed Emin Efendi in the country where he was alleged to subvert the authority and privileges of the nobles of Bzadugh in direct contravention of the firman; to share in the plunder arising from confiscation and fines in the first instance and ultimately to establish his own authority as the vicar of Shamil and to usurp the highest functions of the Hilafet for political purposes. The second point was concerned with the interference of the Ottoman military and administrative officials in the internal affairs of Circassia. Longworth complained about the contemplation of the establishment of Ottoman rule not only in a military sense, but political and administratively as well. For the achievement of this goal, the Porte had appointed to the posts certain persons with powers conferred on them. These persons such as Mustafa Pasha, Sefer Pasha, Behcet Pasha and their subordinates were administering the affairs of Circassia both domestic and foreign of Circassia. This administration was also supported by the Circassians. Not only the Naib but also every native chief had to refer particularly to Mustafa Pasha. Unless they were authorized by him, they could not even communicate with any foreign agents. Under these circumstances, Longworth as the British representative in Circassia, felt humiliated and declared that he had no alternative but to suspend all negotiations with the Circassians, until some further understanding or arrangement be set up in Istanbul. The third point related to the behavior of the Porte's agents on the coast, inhabited by a tribe of Ab- 
hasia who chiefly professed Christianity. The chief of this tribe complained of the Turks who were desirous of establishing Muslim ascendancy there. As the neighboring Christian countries of Mingrelia, Immeritia and Guric were connected by kinship of relations with that of Abhasia, the British representatieve considered it most essential that the Ottoman agents in question should be duly restrained by either withdrawing them altogether from the Chiristian districhts, or insisting that they should in no case be permitted to take any steps there, unless in concert with the agents of the British and French governments ${ }^{21}$.

As soon as the information provided by Longworth with respect to the situation in Circassia, from the point of view of the British interests, reached the British Ambassador, Lord Stratford de Redcliffe, it seems most likely, that he made representation both on the Sultan and on the Porte, so that these complaints be removed and the demands mentioned be met. The lack of correspondence between the British Ambassador and the Porte as to the solution to these problems may indicate that the Porte did not act on British desire. So the affairs of Circassia were not on the agenda, as far as British-Ottoman relations were concerned, from August 1855 to February $1857^{2 ?}$.

21. Longworth to the Earl of Clarendon, no 9, 26 July 1855 , FO 881/1443.

22. From August 1855 to February 1857 I have been able to find only one document concerning the affairs of Circassia. It was sent by the British Consul Stevens from Trabzon, stating that "News has been received by Hafiz Pasha from Circassia, it appears, Russians, having lately crossed the Kuban attacked a Circassian village and massacred a number of its inhabitants". Stevens to Stratford de Redcliffe, no 38, 17 November 1855, FO $195 / 448$. 